\title{
Analysis of the Strengths and Weaknesses of Dutch Water Storage Areas as a Legal Instrument for Flood-risk Prevention
}

\author{
Willemijn van Doorn-Hoekveld
}

PhD candidate, Utrecht Centre for Water, Oceans and Sustainability Law, Utrecht University, Netherlands

w.j.hoekveld@uu.nl

\section{Frank Groothuijse}

Associate Professor of Environmental Law, Utrecht Centre for Water, Oceans and Sustainability Law, Utrecht University, Netherlands

f.a.g.groothuijse@uu.nl

\begin{abstract}
New flood risks require a new flood risk management approach. In the Netherlands there has always been a strong focus on flood defence. However, flood defence in the form of dikes alone will not be sufficient to keep the Netherlands habitable in the future. The 'Room for Water' debate has led to a new legal instrument: water storage areas, which fits perfectly in one of the requirements of the Floods Directive. This relatively new instrument has its own legal framework that is embedded in water law as well as in spatial planning law. This paper analyses the legal framework of the Dutch water storage areas in order to provide a swот analysis that may serve other states that aim to improve their flood risk management strategies.
\end{abstract}

\section{Keywords}

water storage areas - legal framework - Dutch flood risk management - flood risk prevention

* Acknowledgements: The authors would like to thank Marleen van Rijswick and two anonymous reviewers for contributing to the improvement of this manuscript. 


\section{Introduction}

The Netherlands is a country that has a long history of living with and fighting against water. $59 \%$ of the country is susceptible to flooding. The economic heart of the Netherlands, where $70 \%$ of the GDP is produced and which has the highest population density, lies in the low-lying Western part of the country. This makes the country extremely vulnerable to flooding. ${ }^{1}$ There is a delta of four rivers: the Rhine, Meuse, Scheldt and Ems. Natural water systems are very scarce in the Netherlands; almost all water systems have been designated as artificial or heavily modified water bodies under the Water Framework Directive. ${ }^{2}$

Climate change and an increasing flood risk due to ongoing soil subsidence, increasingly heavy rainfall, and surface hardening make it urgent to find new ways to store water in times of high water discharges, because defence in the form of dikes alone will not keep the country safe in the future.

Since the high river discharges in the years 1993 and 1995, the technocratic debate has changed into a more integrated water management debate and eventually led to the 'Room for the River' Programme. ${ }^{3}$ Part of this debate is how to give more space to water in order to prevent flooding, which automatically led to the need for new legal instruments.

In the Netherlands it is a public duty to keep the country habitable and protect the country against flooding. ${ }^{4}$ This article analyzes the legal aspects of the implementation of this public duty of care with a particular focus on the prevention of riverine floods by means of water storage areas. Although an insuffcient transport capacity of rainwater run-off and ground water levels can cause flooding as well, the public duty of care to prevent these types of pluvial flooding will not be addressed in this article. Water storage areas present a specific legal instrument of Dutch flood risk prevention. A water authority can activate these areas to temporarily store water in case of high water discharges of rivers in combination with a great volume of run-off rainwater to regional water systems. Water storage areas are often located on privately owned land. These areas can be used for other functions when they are not used to store water. Since

1 M. Kaufmann, et al., Analysing and Evaluating Flood Risk Governance in the Netherlands. Drowning in Safety, STAR-FLOOD Consortium 2016, p. 8.

2 Directive: European Parliament and Council Directive 2000/60/EC establishing a framework for Community action in the field of water policy, oJ $2000 \mathrm{~L}$ 327/1, Section 2 sub 8 and 9.

3 Kaufmann et al. 2016, supra note 1, p. 30; R. Van der Brugge, J. Rotmans \& D. Loorbach, The transition in Dutch water management, Regional Environmental Change 2005 (5) p. 164. 4 This duty is legally enshrined in legislation. 
2009 there has been a uniform legal framework for the designation, construction, design and activation of water storage areas as well as for the compensation of landowners. Water storage areas can be considered to be a best practice example of Dutch flood risk management and may offer inspiration for flood prevention and mitigation in other countries that cope with similar problems. ${ }^{5}$

At the level of the European Union, the Member States, according to article 7 section 3 of the Floods Directive, are obliged to establish flood risk management plans that include measures for achieving the national objectives for flood risk management. The Floods Directive does not provide any binding safety objectives, nor does it prescribe the use of specific legal instruments to manage flood risks. Nevertheless the Dutch legal concept of water storage areas could be a useful and effective instrument to manage flood risks in other Member States. Article 7.3 of the Floods Directive supports the use of this kind of instruments, where this article states that: 'Flood risk management plans may also include the promotion of sustainable land use practices, improvement of water retention as well as the controlled flooding of certain areas in the case of a flood event.'

In order to describe the Dutch legal framework for water storage areas, this paper firstly addresses the public tasks to prevent floods, then presents in more detail the respective legal instruments of the competent authorities and, lastly, explains the compensation of loss caused by creating water storage areas.

2

\section{The Scope and Assignment of the Public Tasks Regarding the Prevention of Flooding}

According to Section 21 of the Dutch Constitution 'it shall be the concern of the authorities to keep the country habitable and to protect and improve the environment.' In the Netherlands this public care of the physical environment is divided among different authorities of different public bodies at various

5 See for instance the recent floodings in England: $<$ www.theguardian.com/environment/2016/ jan/o2/tory-cuts-wrecking-uk-flood-defences $>$. See also Us Supreme Court Judgment: 568 U.S., Arkansas Game \& Fish Commission v. United States [2012], Journal of Environmental \& Sustainability Law 2013-2014 (20), 93 and B. Hodges, Will Arkansas Game \& Fish Commission v. United States Provide a Permanent Fix for Temporary Takings? Boston College Environmental Affairs Law Review 2014 (41) p. 365 in which the Supreme Court of the us concluded that all physical interferences with private property - regardless of duration - may potentially be subject to the Takings Clause (Fifth Amendment of the us Constitution) and that there is no solid grounding in precedent for setting flooding apart from all other government intrusions on property. Accordingly, the Court held that "government-induced flooding of limited duration may be compensable". 
levels of government. In general, the division of these public tasks concerning the physical environment, as far as relevant for the prevention of flooding, is as follows:

- 23 regional water authorities are responsible for the management of the regional water systems, including the secondary and primary flood defence structures. The Ministry of Infrastructure and the Environment manages the large surface waters, like the rivers Rhine and Meuse, and a number of flood defence structures.

- 393 municipalities are responsible for local spatial planning and the management of public space. In this respect, they have the specific public task to collect, transport and process rainwater run-off, as far as this cannot be reasonably expected from the landowner. ${ }^{6}$ Moreover, the municipalities have the public task to take measures in the public municipal area to preclude or limit, as far as possible, any structurally adverse influence by the groundwater level on the spatial functions of the area, as far as taking such measures is effective and this is not the responsibility of the regional water authority or the province. ${ }^{7}$

- 12 provinces are responsible for regional and supra-municipal spatial planning. Provinces also play a role in the management of regional water systems. The provinces have to assign the management of these water systems to the regional water authority, as far as the management of water systems (or parts thereof) are not assigned to the State. Furthermore the provinces have the important task to coordinate environmental policy at the regional level. This coordination also includes the coordination of spatial planning policy of the municipalities and of the policy of regional water authorities on the management of regional water systems. The provinces supervise the regional water authorities as well as the municipalities as far as environmental tasks are involved. The provinces can be considered an important link between local spatial planning policy by the municipalities and policy on the management of regional water systems by the regional water authorities.

- The State's role is similar to that of the province, but at a greater distance from the local authorities. The State formulates the headlines of spatial planning and water policy as far as it concerns national interests. The State also has a supervisory role regarding the provinces, municipalities and regional water authorities. In addition, Rijkswaterstaat, the national water authority, is responsible for the main waterways and some primary flood defence structures.

6 See Dutch Water Act, Section 3.5.

7 Id., Section 3.6. 


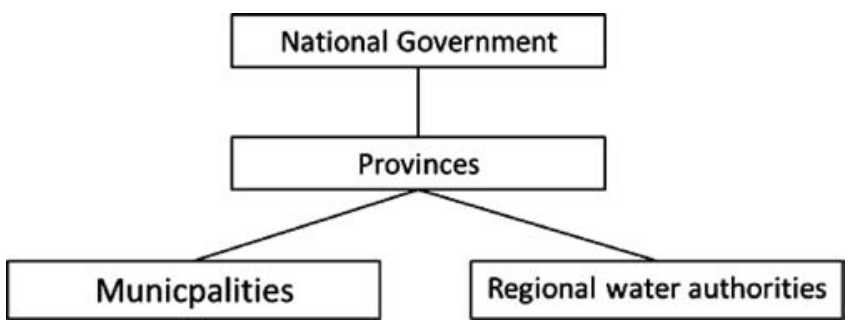

FIGURE 1 Administrative structure of the Netherlands. House of Thorbecke (three tier: national government, provinces and municipalities) with the addition of regional water authorities (source: M. Kaufmann et al., 2016, p. 10).

The Dutch government has the public task to prevent and, where necessary, limit flooding. ${ }^{8}$ This task has to be fulfilled in conjunction with preventing and limiting water shortage, protecting and improving the chemical and ecological status of water systems, and allowing water systems to fulfil societal functions, e.g. drinking water production, leisure, shipping, and fisheries. Because these different public tasks have to be fulfilled in conjunction with each other, this is called the integrated approach of Dutch water management. A specific part of the public task of the prevention of flooding is to ensure that there is sufficient storage and discharge capacity in the regional water system.

This task is elaborated in legal standards with regard to the average annual overtopping probability of designated areas and with a view to determining the appropriate storage and discharge capacity of regional water systems. ${ }^{9}$ The strictness of the standards depends on the land use in the designated areas: the higher the potential financial damage caused by flooding by the regional water system in a certain area, the stricter the standard for that area will be. ${ }^{10}$ For example, grasslands will be subject to a less stringent standard than urban areas. In the end, the regional water system has to be designed in such a way that the storage and discharge capacity is sufficient to meet the standards. Scientific expectations of more intense rainfall could also cause the capture, storage and discharge capacity of the regional water system to no longer meet the standards. Regardless of the cause of the standards being exceeded, the authority that manages the regional water system has to take action by enlarging the water storage and discharge capacity.

The regional water authority is an authority of functional decentralization, which means it is entrusted with a specifically defined responsibility:

\footnotetext{
$8 \quad$ Id., Section 2.1, article 1 under a.

$9 \quad$ Id., Section 2.8.

10 H.F.M.Wvan Rijswick \& H.J.M Havekes, European and Dutch Water Law, 2012, p. 269.
} 
the management of regional water systems. Therefore, the regional water authority must ensure that the standards on capture, storage and discharge capacity for the regional water systems are met. To do so it relies on its own resources, obtained by levying taxes on residents. ${ }^{11}$ Because of the principle of no taxation without representation, residents are able to democratically elect their representatives in the board of the regional water authority. Certain categories of residents with a strong interest in regional water management like farmers or nature conservationists even have guaranteed seats in the representative body of the regional water authority.

The regional water authority does not set the standards for the management of the regional water system, such as capture and storage capacity standards. These standards are set by the province, which is at a higher administrative level than the regional water authority and the municipality, but at a lower administrative level than the State. There is no hierarchy between the regional water authority and the municipality; they are public bodies at the same administrative level. The province is an example of territorial decentralisation, which is concerned with water-related issues in a more strategic manner, but is also concerned with other environmental policies and the implementation of these policies. By setting the standards, the province determines to what extent the designated types of areas should be protected against flooding caused by insufficient water storage and discharge capacity of the regional water system. In this way the province determines how much storage and discharge capacity the regional water authority should create in the regional water system.

\section{Legal Instruments to Fulfil the Public Tasks of Flood Prevention and Legal Recourse for Citizens to Challenge the Use of These Instruments}

\subsection{Introduction}

As noted before, the public duty of care for the physical environment in the Netherlands is divided among different authorities at various levels. The task, competences and legal instruments of these authorities to provide this environmental care are assigned by different laws, each of which protects a specific part of the environment, like water systems, spatial planning, air, soil, noise,

11 See for a more comprehensive explanation of the Dutch regional water authorities: Remco Nehmelman, Institutional governance aspects of water management: subsidiarity and decentralisation - the Dutch approach, The Journal of Water Law 2014 (24), pp. 134-140 and H.F.M.Wvan Rijswick \& H.J.M Havekes 2012, supra note 11, pp. 146-150. 
nature conservation, and monuments. Due to the principle of legality the competent authority can only execute these competences and tasks to protect the part of the environment that they were established for by law. The most relevant for the prevention of flooding caused by insufficient capture, storage or discharge capacity of the regional water system are spatial planning law and water law.

\subsection{Legal Instruments to Enlarge Storage and Discharge Capacity of the Regional Water System \\ Modification of the Regional Water System: Ledger and Project Plan}

In the ledger the water authority has to describe the conditions of the water management structures they manage in terms of orientation, shape, dimension and construction. ${ }^{12}$ Therefore, the ledger does not describe the current actual conditions of a water management structure, but the conditions the structure ought to have. If a regional water management structure fails to comply with the conditions defined in the ledger, the water management structure does not require modification by project, but requires maintenance (or repair) to bring the actual conditions in line with the conditions in the ledger.

However, if a regional water system as described in the ledger does not comply with the provincial standards regarding capture, storage and discharge capacity, the regional water authority that manages the regional water system has the duty to take measures aimed at complying with these standards. Therefore it has to enlarge the storage and discharge capacity of the regional water system. The regional water authority could accomplish this by creating more surface water (horizontally) or raising the dikes that constrain the surface water (vertically). Either way the regional water system has to be modified, because the condition of the regional water system as defined in the ledger no longer complies with the standards.

If the regional authority wants a water management structure to deviate from the normative conditions defined in the ledger, the authority has to establish a project plan, describing, among other things, the modification of the regional water management structure in relation to the normative conditions described in the ledger, the way the project will be executed and how negative effects of the plan will be mitigated or compensated..$^{13}$ Interested parties are able to challenge the project plan before the administrative court. The regional

\footnotetext{
12 Article 5.1 (1 and 2) Water Act.

13 Dutch Water Act, Section 5.4. See H.F.M.Wvan Rijswick \& H.J.M Havekes 2012, supra note 11, p. 273 .
} 
water authority has great discretion in establishing the project plan, so the administrative court will assess the project with restraint to avoid breaching the constitutional division between executive and judicial powers.

\section{Permits for Modifying the Regional Water System}

It is not unlikely that environmental or spatial planning decisions are to be obtained before the regional water authority can actually implement a project plan. If the modification of the regional water system for instance is not in line with the zoning plan, the municipality has to revise the zoning plan or grant a permit to deviate from the zoning plan. It is also possible that the implementation of a project plan will disturb flora or fauna that is protected by the Habitats Directive, which is not allowed without a permit of the Ministry of Economic Affairs. Depending on the circumstances of the case a variety of permits or decisions of various authorities are needed to implement the project plan modifying the regional water system.

\section{Expropriation}

The modification of regional water systems sometimes has to take place on private property. Without the consent of the landowner, the use of his property by the regional water authority for public interest, in this case increasing the storage and discharge capacity of the regional water system to prevent flooding, would be an illegal infringement of property rights. But in favour of this public interest, the regional water authority may ask the State (the Crown) to expropriate the property owner. The Crown has to take the decision to expropriate the landowner. It has to balance the public interest of enlarging the storage and discharge capacity of the regional water system against the interests of the landowner. The necessity and urgency of the expropriation plays an important role in this decision. There is no administrative remedy against the expropriation decision of the Crown. However, arguments against it can be presented before a civil court. The civil court can confirm the expropriation and determine the amount of compensation that has to be paid by the State to the expropriated party. In principle, full compensation is given. The civil court will not approve the expropriation if the expropriating party has not tried to obtain the property by amicable acquisition.

\section{Obligation to Tolerate}

Instead of expropriation, the regional water authority may for the performance of its duties oblige landowners to tolerate the modification of the regional water system, unless the interests of the landowner in its opinion require expropriation. To impose a duty to tolerate the modification of the regional water 
system is the preferred option of the regional water authority. ${ }^{14}$ The decision imposing a duty to tolerate on a landowner can be challenged before the administrative court. The court will take into consideration on the one hand the relation between the part of the property that is affected by the duty to tolerate and the remaining part of the property and on the other hand the degree of residual meaningful use of the affected property. ${ }^{15}$ According to Article 1 First Protocol of the European Human Rights Charter there should be a fair balance between the public interest that is pursued by imposing the duty to tolerate and the legitimate interests of the landowner. In this regard it is relevant that the landowner is entitled to compensation. The Water Act includes a specific compensation regime for this type of loss. The landowner may submit a request for compensation to the regional water authority. The decision on this request can be appealed before the administrative court.

\section{Regulation of Activities in the Regional Water System}

When the regional water system is modified, this modification has to be implemented in the ledger of the regional water authority. The conditions of a regional water system should de facto comply with the ledger. By defining these conditions the ledger also determines where the rules aimed at the protection of the regional water systems apply. These rules are established by the regional water authority, which has a far-reaching regulatory competence. The authority can establish binding rules if these rules according to their assessment are necessary to fulfil the public tasks assigned to them by law. ${ }^{16}$ As mentioned before, the task of a regional water authority is to take care of the regional water system aimed at preventing flooding and water shortage in conjunction with the protection of the chemical and ecological water quality and fulfilling the societal functions of these water systems. For these purposes, the regional water authority can establish binding rules, unless rules established by a higher legislator are meant to be exhaustive. ${ }^{17}$ The only exhaustive rules are those on polluting discharges into regional surface waters. Other activities in the regional water system, such as building constructions or damping, can be and mostly are regulated by the water regulations of the water authority. These rules are usually also aimed at protecting the existing water storage and discharge capacity of the regional water system. These rules in water regulations

\footnotetext{
14 Dutch Water Act, Section 5.24.

15 Judgment of the Administrative Jurisdiction Division of the Dutch Council of State: ECLI:NL:RVS:2013:431, 24 July 2013.

16 Regional Water Authorities Act, Articles 56 and 78.

17 Regional Water Authorities Act, Article 59.
} 
can take various forms: an overall prohibition to undertake activities, a prohibition to undertake activities without a permit, an obligation to report an activity, etc.

The modification of the regional water system also has spatial effects. If land becomes part of the regional water system, the land use may change, e.g. it will become less suitable or no longer suitable for functions that are incompatible with the water-related function. If the applicable zoning plan does not allow the use of land for water-related functions, the municipality has to modify the zoning plan or has to grant a permit to deviate from the zoning plan. The area that will become part of the regional water system should be assigned a waterrelated function. Assigning spatial functions that are incompatible with the water-related function is in violation of proper spatial planning, so the municipality has to remove the current spatial functions that are incompatible with the water-related function from the zoning plan. In the zoning plan the municipality may establish binding rules to protect the spatial functions that are assigned to the land. According to the highest administrative court, the municipality is not competent to establish rules in a zoning plan as far as these rules are aimed at the protection of water system interest mentioned in Article 2.1 of the Water Act that are already protected by the water regulations of the regional water authority. ${ }^{18}$

Although the zoning plan cannot contain rules aimed purely at the protection of water system interests that are already protected by the regulation of the regional water authority, the municipality has to consent if a regional water authority wants to modify the water system in breach of the zoning plan. If the municipality does not want to modify the zoning plan or grant a permit to deviate from the zoning plan for the modifications of the water system, the regional water authority will not be able to modify the regional water system. The regional water authority has no legal instruments to force the municipality to modify the zoning plan or grant a spatial permit to allow the modification of the regional water system, because both public bodies are at the same government level. If there is a dispute between the regional water authority and the municipality, the province - as a higher governmental level - should settle this dispute. ${ }^{19}$ The province has the legal instruments to fulfil this coordinating and supervisory role. Provinces are able to issue binding instructions or instruction rules to the regional water authority as well as to the municipality, as far as

\footnotetext{
18 Judgment of the Administrative Jurisdiction Division of the Dutch Council of State: ECLI:NL:RVS:2015:328, 2 February 2015.

19 See also Provincial Act, Section 174.
} 
the expediency of regional water management respectively provincial spatial interests are at stake. ${ }^{20}$

\subsection{Storage Areas: An Innovative Legal Instrument to Prevent Flooding}

The modification of a regional water system to create more storage capacity in the regional water system, e.g. by enlarging surface waters and/or the relocation or heightening of dikes, generally is quite expensive for the regional water authority. Moreover, these modifications can have a profound effect on private property, requiring space that is scarce in a densely populated delta like the Netherlands and making it no longer available for spatial developments. But there is another more cost-effective way for the regional water authority to enlarge the storage capacity of a regional water system to comply with the provincial storage standards: the designation and construction of storage areas for temporary water storage. ${ }^{21}$ By definition, these storage areas are part of the regional water system, so the storage capacity of a storage area can be taken into account by determination of the total storage capacity of the regional water system. The designation and construction of a storage area can be an efficient solution for the regional water authority to achieve the provincial storage and discharge standards for the regional water system. In the event of intense rainfall the regional water authority intentionally inundates these storage areas under controlled conditions to prevent unintentional and uncontrolled flooding of urbanised areas with a high damage potential. It is an alternative to adhoc cutting the dike in an emergency situation as well.

Since storage areas are only occasionally and temporarily deployed for the storage of water, these areas can be used for other purposes during the time that they are not used for the storage of water, such as agricultural purposes. Typically, relatively low-lying plots that are not used intensively are suitable for the designation as storage areas, because water naturally flows to these plots already and the damage resulting from the use of the storage area is relatively limited. From the perspective of the regional water authority the designation and construction of storage areas may indeed be a relatively inexpensive solution to increase the storage capacity of the regional water system. However, for

$20 \quad O E C D$, Water Governance in the Netherlands: Fit for the Future?, OECD Studies on Water, 2014, pp. 34-35.

21 W.J. Van Doorn-Hoekveld \& F.A.G. Groothuijse, Schadevergoeding ten gevolge van bergingsgebieden: een juridisch labyrint, Agrarisch Recht 2015 (7/8), pp. $35^{8-366}$ and F.A.G. Groothuijse, Bergingsgebieden uniform geregeld in de Waterwet. De aanwijzing, aanleg, regulering en ingebruikname van bergingsgebieden onder de Waterwet, Tijdschrift voor Bouwrecht, 2010, pp. 852-864. 
the landowner who is confronted with the designation of his land as a storage area this can have can have deleterious effects, because he has a legal obligation to tolerate the regional water authority using his land for temporary water storage. Moreover, the landowner will be confronted with other infringements of his property as a result of the designation of his land as water storage area: the regulation of land use by the regional water authority to protect the (effective operation of) the storage area, the obligation to tolerate water management constructions on his land for the effective operation of the water storage area or the protection of buildings against flooding or polluted sediment on their property.

Storage Areas: Four Legal Elements, Four Causes of Damage To establish a storage area, four phases or elements can be distinguished: ${ }^{22}$

1. the designation of a storage area in the ledger and in a zoning plan;

2. the design of the storage area in a project plan and afterwards the necessary construction works;

3. the activation of the storage area (inundation), which entails a legal obligation for the landowner to tolerate it;

4. the regulation of land for the purpose of the storage area.

Ad 1) A storage area is "an area designated for the purpose of water management pursuant to the Spatial Planning Act that is not a body of surface water of part thereof, intended for the expansion of the storage capacity of one or more water systems and registered as storage area in the ledger". ${ }^{23}$ The designation of a storage area in both the zoning plan and the ledger establishes this obligation to tolerate the temporary storage of water in this area for landowners. A complicating factor is that the municipality establishes the zoning plan and the regional water authority establishes the ledger. It is important that the designation of the storage area in both decisions match, because only if the storage area is designated in both the zoning plan and the ledger, is the obligation to tolerate temporary water storage established by law. The zoning plan as well as the ledger can be challenged before the administrative court by interested parties. The usefulness and necessity of the storage area, the compatibility with other spatial functions, the size and geographic location of the

\footnotetext{
22 Judgment of the Administrative Jurisdiction Division of the Council of State ECLI:NL:RV S:2012:BW3869, 25 April 2012.

23 Dutch Water Act, Section 1.1.
} 
storage area and the acceptability of any adverse effects of the deployment of the storage area are relevant here.

Ad 2) For the actual realization of a storage area specific physical measures often have to be taken, such as the placement of an inlet and outlet work, the construction of escape routes, the construction of dikes around the storage area and buildings located in the storage area, etc. For the realization of these physical measures the regional water authority has to establish a project plan. This project plan only allows the regional water authority to take these measures in the storage area and is unrelated to the designation of the storage area in the zoning plan and the ledger. The project plan can be appealed before the administrative court, but the grounds of appeal can only relate to physical measures in the storage area, because of the limited scope of the project plan. The frequency and extent of inundation of the storage area should be taken into account when a project plan is established, according to the highest administrative court. If the cooperation of a landowner is required for the implementation of the project, e.g. for the installation of an inlet and outlet work, and no agreement on cooperation can be reached, the regional water authority may force the landowner to cooperate by imposing an obligation to tolerate the construction of water management structures on his land. This obligation can only be imposed as far as the interests of the landowner require no expropriation.

Ad 3) The regional water authority does not have to issue an explicit order to activate the storage area, since the landowner has to tolerate the inundation of his land by law. So the landowner cannot challenge the actual activation of the storage area, e.g. by opening an inlet construction, before the administrative court. Sometimes a storage area is designed in such a way that it inundates automatically when a certain water level is reached, so the regional water authority does not have to take any action to activate the storage area.

Ad 4) Types of land use or other activities can frustrate the effective operation of a storage area or can have other negative effects on the storage areas, and must therefore be regulated. E.g. large-scale constructions or the cultivation of expensive crops in a storage area should be prohibited or regulated. The question is which authority should regulate these types of land use or activities. The regional water authority is competent to establish binding rules as far as these rules are aimed at its legal task, including the protection and proper operation of the regional water system. Since storage areas are part of the regional water system, the water authority is competent to establish binding rules to protect storage areas and their proper operation in water regulation. On the other hand the municipality is competent to establish binding rules in the zoning plan aimed at proper spatial planning. Because the 
storage area is designated as a spatial function, the municipality is also competent to establish binding rules on land use to protect the storage area and its proper operation. As mentioned before, the highest administrative court has established that no binding rules to protect water-related interests in a zoning plan can be established as far as the water regulations already protect these interests or the power to do so. ${ }^{24}$ Therefore, the regional water authority is exclusively competent to regulate activities aimed at the protection of the regional water system with regard to the objectives of the Water Act: flood protection, protection of water quality, and the fulfilling of societal functions of water systems. ${ }^{25}$

\section{$4 \quad$ Regional Water System Management and the Establishment of Zoning Plans}

Proper cooperation and coordination should take place between the regional water authority and the municipality on the designation, management and regulation of storage areas. The cooperation of the municipality is required for modifications of water systems if these modifications do not fit within the municipality's zoning plan. On the other hand, the municipality has to take into account the spatial restrictions resulting from the rules and policies of the regional water authority when establishing a zoning plan. If the rules and policies of the regional water authority preclude the feasibility of a zoning plan, the plan does not constitute proper spatial planning and therefore cannot be established. To coordinate the establishment of a zoning plan with the policy of the regional water authority the so-called "water test" or "water assessment" was created. This means that a regional water authority assesses the draft of a zoning plan for compatibility with its policies and regulations and advises the municipality before the zoning plan is established. In this process the results of the water assessment will be discussed with the municipality. However, the advice of the regional water authority is not legally binding, which means that the municipality can deviate from the advice.

24 Judgment of the Administrative Jurisdiction Division of the Council of State, ECLI:NL: RVS:2015:328, 2 February 2015.

25 See F.A.G. Groothuijse, Water weren. Het publiekrechtelijke instrumentarium voor de aanpassing en bescherming van watersystemen ter voorkoming en beperking van wateroverlast en overstromingen, 2009. 


\subsection{Liability for Damage Caused by Fulfilling the Public Task}

In the above sections the public duty to prevent flooding caused by insufficient storage and discharge capacity of the regional water system has been discussed as well as the legal instruments to fulfil this duty. While fulfilling this task the competent authority can cause losses for landowners, because the land use is restricted by binding rules in order to protect the storage and discharge capacity of the regional water system, or by obligations to tolerate the inundation of their land for the enlargement of the storage and discharge capacity of the regional water system. The use of legal instruments to fulfil a public task, e.g. expropriation, regulation of property or imposing obligations to tolerate, may cause losses to private parties, just as a factual act, e.g. the operation of a sluice or a pumping station, may also cause loss, for example loss of income or devaluation of property. ${ }^{26}$

Modification of the regional water system can have a negative impact on interested parties, for instance landowners of adjacent plots or users of the regional water system. In addition to legally challenging the project plan before the administrative court, these injured parties can claim damages pursuant to a damage compensation regime for lawful acts by the government.

Usually the compensation regime of the Water Act is applicable if citizens suffer damage caused by lawful government acts aimed at enlarging the storage or discharge capacity of the regional water system, because these acts are initiated by the regional water authority to fulfil its public water management task. Pursuant to Article 7.14 of the Water act: 'Any person who suffers or will suffer damage as a consequence of the lawful exercise of a water management duty or competence shall, at his request, be awarded compensation by the administrative authority concerned where such damage should not within all fairness remain for his account and where compensation is not or not sufficiently otherwise guaranteed.' The compensation regime is regulated in Paragraph 3 of Chapter 7 of the Water Act and is based on the principle of 'égalité devant les charges publiques'. According to this principle, compensation should be provided for those who have shouldered a disproportional large burden or loss caused by activities pursued for the common good. ${ }^{27}$ According to Dutch

26 W.J. van Doorn-Hoekveld et al., Distributional effects of flood risk management - a crosscountry comparison of pre-flood compensation, Ecology and Society 2016 (21), p. 26.

27 D. Fairgrieve, State liability in Tort: A Comparative Law Study, 2003, p.137; W. van DoornHoekveld, Compensation in Flood Risk Management with a Focus on Shifts in Compensation regimes Regarding Prevention, Mitigation and Disaster Management, Utrecht Law 
law this principle is only applicable if the burden or loss is imposed by a lawful government action. This action can consist of a public law act, such as a decision, or another factual act, like the operation of a sluice.

Not every loss caused by a lawful government action is eligible for compensation. There are strict conditions to assume liability. As mentioned above, the loss of the injured party must qualify as an abnormal and special burden. ${ }^{28}$

Damage caused by the obligation to tolerate the use of private property by the regional water authorities for the storage of water in favour of the public interest (prevention of flooding elsewhere) should be fully compensated.

The regional water authority is competent to decide on an application for compensation, if the damage is caused by the lawful exercise of their legal task and competences. When an applicant for damages disagrees with the decision of the competent authority on his application, he can challenge this decision before the administrative court. The existence of this legal compensation regime often enables the regional water authority to move the discussion about adverse effects of the appealable decision, like a project plan, from the procedure against the project plan to a separate procedure about damage compensation. The compensation regime of the Water Act frequently this works as a 'lubricant' for taking decisions about the construction or modifications of infrastructural works.

The administrative court will assess the project plan with restraint (see section 3.2), so the chances of a successful appeal are relatively limited. More specifically, the administrative court assesses whether the adverse consequences of the project plan for the claimants are disproportional or not. However, since claimants are entitled to claim damages according to the above described compensation regime, the administrative court is reluctant to incriminate the adverse effects of the project plan as disproportional. After all, the adverse effects of the project plan can be balanced by granting damages to the claimants pursuant to the compensation regime in the Water Act.

\subsection{Complications: Two Responsible Administrative Authorities}

It is not always easy to determine whether the compensation regime of the Water Act or the regime of the Spatial Planning Act is applicable to the designation of storage areas, because different authorities have to designate

Review 2014 (10), pp. 230-234; G.M. Van den Broek, Compensation for damage within a systematic approach to large-scale water and infrastructure projects, The Journal of Water Law, 2015(24), pp. 266-271.

28 See the Administrative Jurisdiction Division of the Council of State, ECLI:NL:RVs:2013: BZ7718, 17 April 2013. 
the storage area on two different legal bases. ${ }^{29}$ The designation of a storage area can cause damage to a landowner, because plots designated as storage areas may decrease in value. A landowner whose land is designated as a storage area can claim the damage thus caused under two different compensation regimes: the compensation regime in the Spatial Planning Act, because of the designation in the zoning plan, and the compensation regime in the Water Act, because of the designation in the ledger. These two compensation regimes show similarities. Both are based on the aforementioned principle 'égalité devant les charges publiques', but there are some important differences too. The compensation regime in the Spatial Planning Act is only applicable to damage caused by the public-law decisions mentioned in Section 6.1, ${ }^{30}$ while the compensation regime in the Water Act is applicable to damage caused by lawful public-law decisions as well as lawful factual acts. Unlike the compensation regime in the Spatial Planning Act, the compensation regime in the Water Act does not require the applicant to pay a fee for handling the application. ${ }^{31}$ Moreover, different authorities are competent to decide on the application. The regional water authority is competent to decide on an application pursuant to the compensation regime in the Water Act, while the municipality is competent to decide on an application under the Spatial Planning Act. Because of the dual legal basis of the designation of a storage area, there is also a dual legal basis to apply for damages. This means that a landowner can choose between both compensation regimes to claim his damage caused by the designation of his plots as storage area. Obviously he cannot claim the same damage twice by applying for compensation under both regimes, because these regimes do not award compensation as far as the compensation is otherwise guaranteed or has already been awarded under another regime.

To prevent the injured party from claiming the same damage on the basis of two different compensation regimes, the legislator has introduced a priority rule. This priority rule states that the compensation regime of the Spatial Planning Act will not be applied where an injured party can claim compensation on the basis of the compensation regime of the Water Act. ${ }^{32}$ The aim of

29 See W.van Doorn-Hoekveld 2014, supra note 28, p. 216-238.

$30 \quad$ Article 6.1 provides a regulation for the compensation of planning blight.

31 This handling fee was introduced in the Dutch Spatial Planning Act to raise a threshold against unmeritorious applications. The handling fee will be returned if the application for damages under the Spatial Planning Act is granted partly or in full. 
this priority rule is to compensate damage caused by the exercise of competences or powers on the basis of the Spatial Planning Act in favour of water management under the compensation regime of the Water Act. ${ }^{33}$ Because of the priority rule, the landowner has to claim his damage caused by the designation of a storage area in a zoning plan on the basis of the compensation regime of the Water Act, where he should normally claim damage caused by a zoning plan on the basis of the compensation regime of the Spatial Planning Act. For the landowner it is therefore clear that he can claim all the damage caused by the designation, management and deployment of storage areas on the basis of the compensation regime of the Water Act.

This priority rule is also efficient from an administrative perspective, because storage areas are designated to fulfil the public task of the prevention of flooding caused by an insufficient water storage and discharge capacity of the regional water system. Because this public task is a responsibility of the regional water authority, the regional water authority should compensate all damage caused by the execution of competences to fulfil this task, such as the designation of storage areas in a zoning plan. It would be cumbersome for the municipality to first compensate the damage caused by the designation of a storage area in a zoning plan and subsequently reclaim the damages paid from the water authority.

\subsection{Reimbursement Rule}

Although the priority rule is quite clear, the case law about its application causes some confusion regarding the damages that can be claimed from the municipality or the regional water authority. However, the Spatial Planning Act provides for another legal arrangement for municipalities to reimburse the damages they paid because of the designation of a storage area in a zoning plan from the regional water authority. This arrangement grants municipalities the possibility of being reimbursed for damages paid due to spatial planning decisions taken to fulfil the public tasks of another authority, in this case the task of the regional water authority to prevent flooding. If the regional water authority does not voluntarily reimburse the costs caused by the designation of the storage area in the zoning plan, the municipality can request the province to force the regional water authority to reimburse these costs to the municipality. ${ }^{34}$

\footnotetext{
33 Explanatory Memorandum of the Dutch Water Act: Parliamentary Proceedings 2008/og, $3185^{8}$, number 3, pp. 36-37.

34 Dutch Spatial Planning Act, Section 6.2.
} 


\subsection{Liability for Damage Caused by Neglecting the Public Task}

In addition to liability for damage caused by fulfilling the public task of preventing and limiting flooding caused by an insufficient storage and discharge capacity of the regional water system, neglecting this public task can cause damage too. This liability is based on tort, because the damage is caused by an unlawful act, consisting in negligence regarding a public task. If flooding occurs because the regional water system is not able to process the water discharge and this water system does not comply with the storage and discharge standards, the question is to what extent the regional water authority is liable for loss.

As specified above, the regional water authority is only liable for the damage if it has been attributably negligent in fulfilling its public task of prevention and reduction of flooding, set out in the storage and discharge standards. This means that the regional water authority will not automatically be liable if the regional water system does not fulfil these standards. Although the standards indicate the scope of the public task of the regional water authority, they do not establish liability if a flooding of the regional water system occurs, even if the regional water system does not meet these standards. However, if the water system does not comply with these standards, this could be an indication that the regional water system failed to properly fulfil its public task and the regional water authority could be liable for any loss that would not have occurred if the water system had complied with the standards. Nevertheless, if the regional water authority can reasonably justify the non-compliance with the storage and discharge standards, it can avoid tort liability. In case law, the prioritization of measures by the regional water authority, the limited availability of financial resources and personnel, the required permits and decisions of other authorities to enlarge the storage and discharge capacity of the regional water system, including the associated lengthy procedures, have been accepted as justifications, provided they were based on proper reasoning. ${ }^{35}$ Hence, the standards indicate what the water management of the regional water authority should aim for, but they provide no guarantee for landowners that the regional water system will achieve these standards at any time and in any circumstance.

35 Judgment of Court of Appeal, ECLI:NL:G HARN:2000:AA6319, 20 June 2001. More in general on liability for neglecting the public task by the regional water authority see the following judgments of the Supreme Court of the Netherlands: ECLI:NL:HR:1981:AG4240 of 9 October 1981; ECLI:NL:HR:1999:ZC2813 of 8 January 1999; ECLI:NL:HR:1999:AA1058 of 19 November 1999 and, ECLI:NL:HR:2001:AD5302 of 9 November 2002. 
In this paragraph we analyse the instrument of water storage areas. For this purpose we use the swot analysis, which shows the strengths, weaknesses as well as the opportunities and threats of the water storage area as legal flood risk management instrument.

\section{Strengths}

1. Presence of legal framework

2. Efficient land use

3. Cost-effective solution for insufficient water storage

4. Legal framework for compensation of loss

5. Legal certainty

6. Damage control/loss prevention

\section{Opportunities}

12. Provinces can take the lead because of supervisory competences

13. Bridging mechanism

14. Priority rule

15. Arrangement for reimbursing costs

\section{Weaknesses}

7. Procedures for designation are unclear

8. Procedures for compensation are unclear

9. Costs for designating and constructing water storage areas

10. Infringement of property rights

11. Restrictions to land use

\section{Threats}

16. Regional water authority is dependent on other authorities

17. Provinces do not actively participate

18. Fragmented administrative authorities

19. Soil pollution after the activation of the area

In general, the presence of a legal framework can be seen as a great advantage of the Dutch water storages (1). However, the procedural rules may cause some confusion, because the storage area must be designated by two different authorities - the regional water authority and the municipality - and because it is not clear to all parties which authority is responsible for compensating the loss resulting from the designation $(7,8) \cdot{ }^{36}$ The Water Act provides a solution for this problem with the Priority Rule of Article 7.16. This rule states that the compensation regime of the Spatial Planning Act will not be applied where

36 Van Doorn-Hoekveld and Groothuijse 2015, supra note 22. 
an injured party can claim compensation on the basis of the compensation regime of the Water Act. The aim of this priority rule is to compensate damage caused by the exercise of competences or powers on the basis of the Spatial Planning Act in favour of water management under the compensation regime of the Water Act (14). ${ }^{37}$ Another possible solution is that the municipality pays the loss of injured parties and claims it back from the regional water authority, because by designating a storage area the municipality partly performs a public task that belongs to the regional water authority. Dutch law provides for a legal arrangement to reimburse costs that a public authority has incurred performing the public tasks of another authority. The province plays a coordinating role when the authorities concerned are municipalities and regional water authorities. ${ }^{38}(15)$.

One should bear in mind that the Netherlands is a densely populated country. Flood prevention measures will in almost every case affect property that is privately owned. Water storage areas in most cases are owned by private parties and therefore infringements of property rights will occur, not only leading to dispossession of property, but also to restrictions on the use of land $(10,11)$. The advantage, however, is that land use is more efficient, because it can be used to temporarily store water in case of high water discharges, but the rest of the year it can be used by the owner, in most cases as agricultural land $(2,3)$. The fact that a specific area is designated as water storage area leads to legal certainty (5). Because the owner knows about the consequences of the area used as a water storage area, he can prevent or limit loss caused by the area being flooded, by taking necessary measures (6). Also, the injured parties do have a possibility to claim compensation for their loss (4).

The costs for designating and constructing the storage area can be seen as a weakness, but the costs of cutting the dike in an emergency situation will be much higher (9).

The regional water authorities do not have the competences to create a water storage area on their own, but depend on municipalities, which can be seen as threat, because the interests of water managers and municipal spatial planners may differ. An unwilling municipality can prevent the creation of a water storage area $(16,18)$. The provinces could solve this problem, because they have supervisory competences to influence or overrule the exercise of duties or competences of both municipalities and regional water authorities. At a regional level the provinces coordinate water and spatial planning policy. The province can ultimately decide whether and where a storage area should

37 Explanatory Memorandum of the Dutch Water Act, supra note 34, pp. 36-37.

38 Dutch Spatial Planning Act, Section 6.2. 
be designated or not $(12,17)$. At the same time, these weaknesses also provide strength: the instrument can be seen as a so-called 'bridging mechanism'. ${ }^{39}$ The fact that both the municipality and the regional water manager need to designate an area as water storage area will enhance cooperation between the two. In addition, the province has another important bridging mechanism: their water plans may include spatial reservations for water storage areas and oblige both the municipality and the regional water authority to include them in their plans (13).

\section{7}

\section{Conclusion}

The analysis of the strengths and weaknesses of the instrument of water storage areas shows that there are two sides to the same coin. Advantages and disadvantages of storage areas are connected. However, in our opinion, in densely populated areas the advantages outweigh the disadvantages. For densely populated areas with intensive use of space like the Netherlands, the use of water storage areas is a cost-effective solution to prevent flooding, because these areas can be used for other purposes like growing crops or livestock grazing when they are not used for water storage.

Legal certainty is one of the major advantages of this Dutch concept. Owners know their rights and their duties. Different legal arrangements for compensation accommodate for cases of infringement of property rights.

In addition, because water storage areas may be considered as a bridging mechanism, they may serve to increase the cooperation between regional water managers and municipal spatial planners. Moreover, the province has to take its coordinating and supervisory role seriously by setting clear policy frameworks on flood prevention for municipalities and regional water authorities. If these authorities disregard these frameworks the province should not hesitate to use its intervention competences. Although the cooperation between the different competent authorities is a challenge, legal arrangements are available to solve these cooperation problems. But legal arrangements alone are not enough. The authorities involved should invest in long-term relationships in order to build a strong bridge over increasingly troubled waters.

39 Bridging mechanisms are defined as "Instruments that remedy fragmentation by enhancing interconnectedness between relevant actors through information transfer, coordination and cooperation", see H.K. Gilissen et al., Bridges over Troubled Waters - An Interdisciplinary Framework for Evaluating the Interconnectedness within Fragmented Flood Risk Management Systems, Journal of Water Law 2016 (25), pp. 12-26. 